\title{
Dietary Polysaccharides from Allium Species: A Critical Review in Dietary Polysaccharides from Allium Species: Extraction, Characterization, Bioactivity, And Potential Utilization
}

\section{Dery Bede ${ }^{1,2 *}$ and Lou Zaixiang1,2}

${ }^{1}$ State Key Laboratory of Food Science and Technology, School of Food Science and Technology, Jiangnan University, PR China

${ }^{2}$ National Engineering Research Center for Functional Food, Jiangnan University, China

*Corresponding Author: Dery Bede, State Key Laboratory of Food Science and Technology, School of Food Science and Technology, Jiangnan University, PR China and National Engineering Research Center for Functional Food, Jiangnan University, China

DOI: $10.31080 /$ ASAG.2020.04.0780
Received: January 17, 2020

Published: January 24, 2020

(C) All rights are reserved by Dery Bede and Lou Zaixiang.

\begin{abstract}
Allium species are broadly used as a functional food and nutraceutical products because of its recognized nutritive and medicinal properties. It has been used since antiquity in Asia as a traditional medicine for the management and treatment of conditions such as diabetes, hypertension, cancer, inflammation, gastrointestinal problems as well as microbial infestations. There have been studies over the past decade on the extraction of the bioactive compounds from various Allium species and both in vivo and in vitro experiments suggest that Allium species can be used as an alternative in preventing and managing diseases stated in this paper. This review summarizes the recent developments of Allium species polysaccharides, including their production, extraction and isolation methods, chemical structures, biological and pharmacological properties and mechanism of actions.

Keywords: Allium Species; Polysaccharides; Extraction Methods; Cardiovascular Disease
\end{abstract}

\section{Introduction}

Despite severe intervention and strategies adopted by World Health Organization (WHO) over the years to curtail the escalated rate of diseases, current statistics rather show a high prevalence of diseases. In 2012, Non-Communicable Diseases (NCD) accounted for about 38 million death constituting $68 \%$ of all death globally. Premature death, which is determined by WHO as a death below the age of 70 years, accounted for $52 \%$ due to NCD. In the latest statistics, over three-quarters of the deaths that were as a result of NCDs was cardiovascular disease, Diabetes and Cancer [1]. Cardiovascular disease is a broad term for disorders of the heart and blood vessels of which heart attack and stroke are the common indications. In 2012, 17.5 million deaths which were as a result of cardiovascular disease represented $31 \%$ of global death [2]. Cancer which is the second leading cause of death worldwide after cardiovascular disease is expected to be the number one cause of death in this $21^{\text {st }}$ Century because of increased globalization and industrialization which has also increased exposure to carcinogens such as polycyclic aromatic hydrocarbons from cigarette smoking and fumes from car exhaust and industries, alcohol, harmful chemicals, radiations and infectious agent [3].

For a decade now, much attention has been dedicated to the extraction and analysis of polysaccharides from natural sources such as plants, animals, and microorganism due to its essential bioactive compounds which plays an important role in biological activities such as antitumor, antioxidants, anticoagulation, antidiabetic, neuroprotective and immunity enhancer [4]. Given their strong antioxidant, antidiabetic and lipid reducing effect, the effect of dietary polysaccharides from ganoderma lucidum on streptozo- cin induced diabetic rat was studied and the results proofed positive because there was a drastic reduction in lipid peroxidation, blood glucose level and increased enzymatic and non-enzymatic antioxidants against normal rat which was induced with diabetes but didn't receive G. lucidum polysaccharides treatment [5]. Polysaccharides from Phellinus linteus have also exhibited extended survival rate of B16F10 implanted mice, inhibited tumor growth in NCI-H23 implanted nude mice and reduced frequency of pulmonary metastasis of B16F10 melanoma [6]. In the cosmetic industries, Sulfated Polysaccharides, such as concentrated fucoidan from undaria pinnatifida is used in creams and other skin products to protect the skin from ultraviolet irradiation, smoothens the skin to prevent wrinkles [7]

In recent years, several researches have verified that dietary polysaccharides from Allium species together with its phytonutrient helps in the prevention, management, and treatment of numerous diseases including cancer, diabetes, coronary heart disease, overweight and obesity, hypercholesterolemia, type 2 diabetes, cataract as well as for the treatment of worms and bites [9]. Allium species also have the capacity to excite immunological responsiveness and its modulation of prostanoid synthesis because of its antioxidant, anticoagulation, antiviral, antitumor, myocardial protection, immunity enhancement, hypolipidemic and hypoglycemic function [10].

Allium is among the well-known genus which comprises about 900 species with about 140 species known and used in China. It is widespread mostly in mountains of central Asia specifically Afghanistan, Tajikistan, Pakistan, parts of Serbia and largely produced in China followed by India. The Allium genus can also be found in Eu- 
rope, North America and Africa [11]. The commonest of this species that is almost found in the cabinets of all kitchen is the Allium cepa (onion) and Allium sativum (garlic) which have been used since antiquity as flavor-enhancing agent in cooking and having the ability to eliminate so many diseases. In previous studies, not only does Allium species exhibit immunostimulatory, antidiabetic, reduction in serum lipid and total cholesterol levels but also hepatoprotective properties having the tendencies to reduce high levels of aspartate aminotransferase (AST), alanine aminotransferase (ALT), alkaline phosphatase (ALP) and total bilirubin [10]. The physicochemical properties, biological properties and chemical structure of Allium species polysaccharides have to be studied extensively in other to understand properly their medicinal properties.

Therefore this overview presents a comprehensive review of the various extraction methods, Isolation mechanisms, physicochemical, biological, structural and functional characteristics of the different types of Allium species polysaccharides. This overview will enhance the understanding of Allium species polysaccharides and facilitate further studies on the distinct structures, properties, bioactivity and potential application in health and functional foods.

\section{Allium species and bioactive compounds}

According to the 2016 statistics of the Food and Agriculture Organization, the leading producer of Allium species was Asia which constitutes $65.5 \%$ followed by European countries constituting $10.9 \%$. In Asia, China is the leading producer of Allium species producing $23,849,005$ tonnes of onion per year, India also producing about 19,415,425 tones of onion whiles Egypt and the United State of America also collectively produce approximately 3,000,000 tones of onion. Not only China leads in Onion production but also leads in the production of garlic, which is estimated to be producing about $75 \%$ of world tonnage according to Food and Agriculture Organization followed by United state behind India and the Republic of Korea [12]. Allium sativum, commonly known as garlic, which happens to be in the family of Alliaceae was proposed to have been originated from the Tian Shan Mountains, which stretches from Kazakhstan through to Kyrgyzstan's and Xinjing Uyghur of Western China and subsequently in the Mediterranean and Caucasus zone [13]. China is the leading producer of garlic worldwide followed by India and the United State of America according to the 2016 Food and Agriculture Organization Statistics. It is also among the plant species which has attracted the most attention to the human race because of its medicinal properties with the tendencies to managing and treating several diseases [14]. Numerous studies over the past years have confirmed its biological properties such as hypoglycemic effect which makes it suitable for diabetes patients, hypocholesterolemic properties which is best for controlling or managing dyslipidemia, rich in antioxidants for free radicals scavenging, anticancer properties which reduces one's risk of cancer and anti-obesity effect by decreasing the expression of adipose gene hence weight loss [15]. The constituent of raw garlic is water, carbohydrates, protein, fat, essential amino acids, vitamins, minerals and dietary fiber. Raw garlic contains 59\% moisture, 33\% carbohydrates, $6 \%$ proteins, $2 \%$ dietary fiber and $0.5 \%$ lipids and $1.1-3.5 \%$ organosulphur compounds which translate into figures as $58.6 \mathrm{~g}$ moisture, $6.4 \mathrm{~g}$ protein, $33.1 \mathrm{~g}$ carbohydrates, $2.1 \mathrm{~g}$ fiber and $0.5 \mathrm{~g}$ lipids [16]. Garlic bulbs are used as a spice or condiments in various dishes whether raw or uncooked. The leaves and immature inflorescence and stalk are eaten as vegetables [13].

The second commonest species in the Allium genus used in the world is the Allium cepa, which is commonly called Onion. It is one of the most essential vegetables with the world tonnage of about 64.5 million according to Food and Agricultural Organization 2009 statistics which is an increase of more than $25 \%$ since 2004 [17]. China and India have always been the leading producer of onion producing 22,600,000 tonnes and 16,308,990 tonnes respectively according to Food and Agriculture Organization 2013 statistics followed by the United States producing 3,277,660 tonnes and in Africa, Nigeria is the leading producer producing about 1,350,000 tonnes of onion [18]. Fresh Onion has about $80-95 \%$ moisture and has low levels of carbohydrates, proteins, fiber and lipids as compared to garlic. Per $100 \mathrm{~g}$ of fresh onion, it contains $89.1 \mathrm{~g}$ of water, $1.1 \mathrm{~g}$ of protein, $9.3 \mathrm{~g}$ of carbohydrates, $4.2 \mathrm{~g}$ of fiber, $0.1 \mathrm{~g}$ of lipids and vitamins and minerals range from $0.2 \mathrm{~g}$ (irons) to $146 \mathrm{~g}$ (Potassium) (Putnik., et al. 2018). The rising level of the production and consumption of onion is attributed to its nutritional, medicinal and functional properties [19]. Previous studies have demonstrated the effectiveness of onion in combating several diseases due to its antidiabetic and antihypertensive effect which has the tendencies to constrain angiotensin-converting enzymes, a-amylase, and aglucosidase and also with the ability to scavenge DPPH free radical. Quercetin present in onion makes it a good supplement for the prevention of thrombosis and cardiovascular-related diseases [20]. Other studies also report onion's effectiveness as anticancer, antimutagenic, antiasthmatic, anti-cholesterolemic and antimicrobial properties [19]. Onions are used in food preparation either cooked or uncooked as vegetables and also used to improve the palatability of food [11].

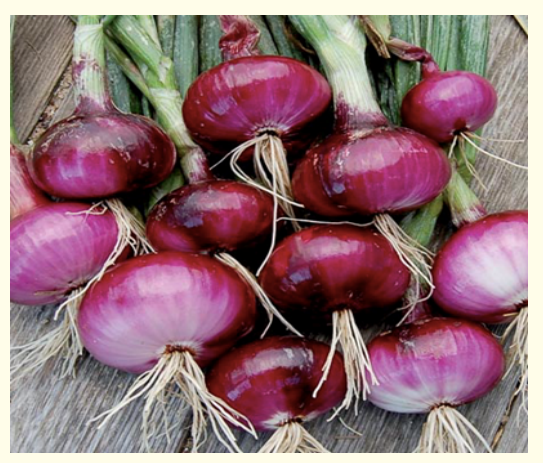

Figure 1: Stalk, bulb and roots of reddish skin onion (seedsaver.org).

Chinese leeks, Allium tuberosum, is another species in the Alliaceae family mostly known to the southwestern parts of the Chinese Province, Shanxi. Not only is Chinese leeks known for its edible value, but two thousand years ago, Chinese farmers realized that when leeks are intercropped in a farm, the crops are less susceptible to pathogenic infection because of its ability to exert control on microbial pathogens [20]. Chinese leeks also have in abundance 
nutrients of which moisture is the highest constituting $83.0 \mathrm{~g}$, carbohydrates $14.2 \mathrm{~g}$, proteins $1.5 \mathrm{~g}$, total lipids are $0.3 \mathrm{~g}$, minerals range from $0.1 \mathrm{~g}$ to $180 \mathrm{~g}$ whiles vitamins also range from $0.03 \mathrm{~g}$ to 1667g. The seed of Chinese leeks are known as Allium tuberosum Rottler, is collected after harvesting of matured leeks and then dried. The seed is rich in oil, crude protein and dietary fiber according to $15.8 \%, 12.3 \%$ and $18.2 \%$ respectively and can be used as a source of protein. Its fresh leaves are also used for cooking and as a traditional medicine for the treatment of impotence, gastric ulcer, Dyspepsia, nocturnal emission, abdominal pain and for kidney protection [21]. Pharmacological and Biological activities of Chinese leeks such as anticancer, antidiabetic, antioxidant, antimicrobial, aphrodisiac, cytoprotective, hepatoprotective properties have in the past decade been reported [20].

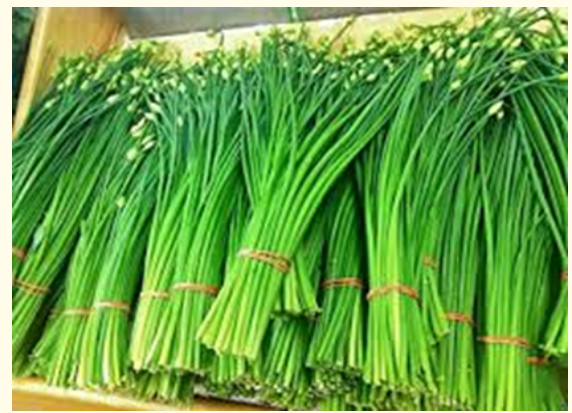

Figure 2: Harvested Chinese Leeks (johnnyseeds.com).

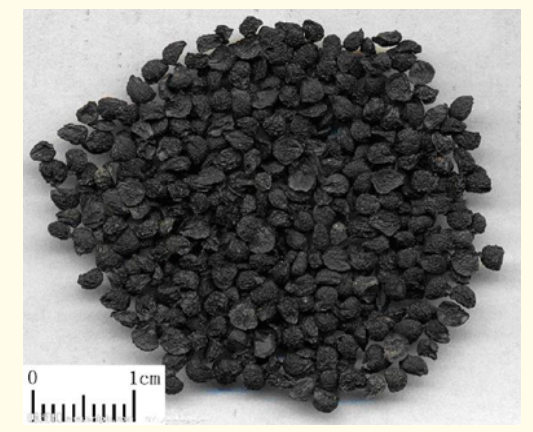

Figure 3: Dried Chinese leeks seeds (tcmwiki.com).

Elephant garlic has its botanical name to be Allium ampeloprasum var. ampeloprasum. It has the shape of leek and closely similar to garlic but it is not a true garlic. It was first discovered in America by an American nurseryman in an abandoned garden back in 1941 . Worldwide, Georgia is the leading producer of Elephant garlic. Few pieces of research have been conducted on elephant garlic but the available literature proofs elephant garlic's antioxidant and antiinflammatory properties [22].

Allium ascalonicum L. also known as shallot is most common in Europe and in some parts of Asia such as India, Singapore, Indonesia and Brunei. They look like onions but differ from common onion in terms of how the bulbs are formed. Shallots tend to form a cluster of small bulbs as garlic. Shallot has been known since antiquity because of its edible value and its health benefit for traditional medicine. It has been recognized for its hypoglycemic, antioxidant, hypocholesterolemic, antibacterial and antifungal effect [23].

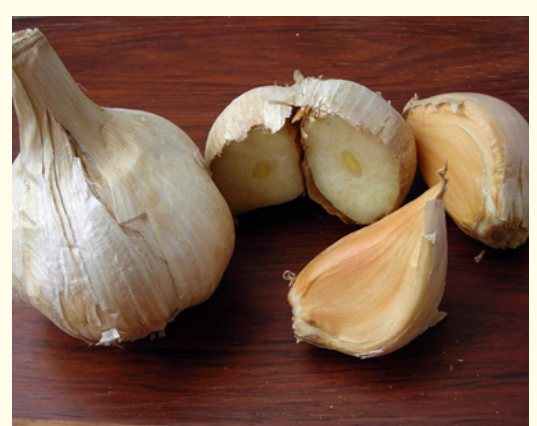

Figure 4: Bulb of Elephant garlic.

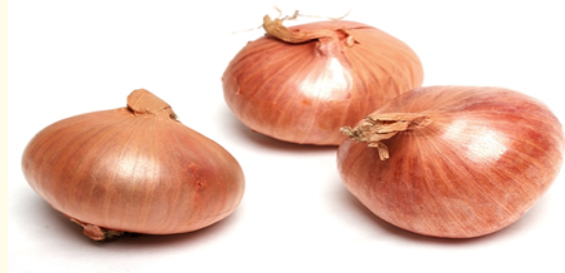

Figure 5: Bulb of shallots (milissa.com).

Allium ursinum L. is commonly called wild garlic. It is widespread in Europe, Asia Minors, Caucasus, and Serbia but stretches to the Kamchatka Peninsula. It is also well-known for its edible and medicinal properties which have been attributed to its sulfur-containing compounds. Wild garlic possesses several biological activities such as antioxidant, antiplatelet, cardioprotective, cytostatic, antimicrobial, anti-inflammatory and anti-diabetic properties [24].

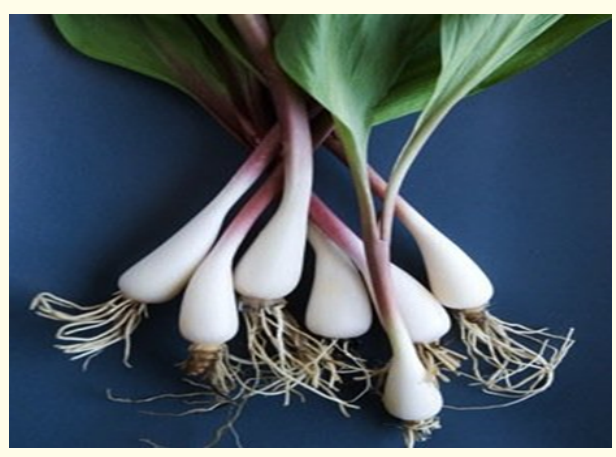

Figure 6: Bulb, roots and stalk of wild garlic (mlive.com).

Allium schoenoprasum has a common name as Chives and known for its edible and medicinal effect on the human. It is mostly found in South Wales, 18km along the River Wye in Powys. It strives well in the bedrock where the clumps of the bulb are usually found firmly embedded in the rock crevices. In Israel, Chives are cultivated mainly on artificial media in a greenhouse. This species can reproduce both sexually and asexually. Sexual through seeds and asexually by the production of daughter bulbs from short rhizomes. Allium schoenoprasum have been scarcely studied recently but the little research available indicates that Allium schoenopra- 


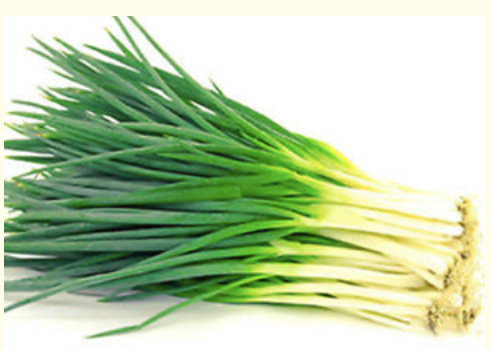

Figure 7: Chives (onlyfoods.net).

Allium macrostemon Bunge is an edible and medicinal species in the Amaryllidaceae family, which is popularly known in China especially in the north and northeast parts of China. It is also well known in Korea and Japan. The fresh bulb of Allium macrostemon Bunge is used as vegetables in most homes while the dried bulbs are used as traditional medicine. There are several types of research that have been carried out over the past decade to confirm its biological and pharmacological properties and it was proven to be potent source antioxidant, anticancer, antihypertensive, antidiabetic, antiobesity, hypoglycemic, hypolipidemic, anti-depressant-like activities, inhibitory activities against human platelet aggregation as well as protection from cancer [26].

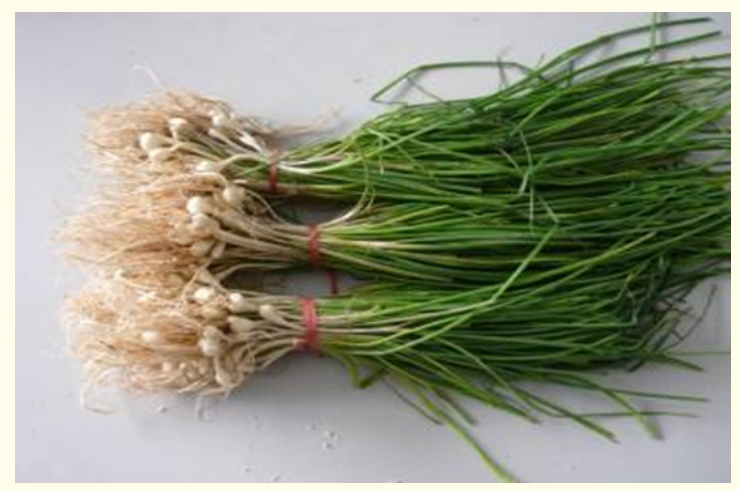

Figure 8: Allium macrostemon Bunge (sou rce: hebalextractin.com)

Also known is tropical Asia, Siberia as well as Japan, Korea and China is an Allium fistulosum, which is commonly known to most people as Welsh onion. It is often used in Japan as a vegetable for cooking even though it is also strongly used in China. It has also been used as a functional food for the treatment of headaches, abdominal pain, diarrhea and cold. Researchers have also studied its biological and pharmacological properties and have found out to be a good antifungal, antibacterial, antihypertensive, antiplatelets, and antiobesity [27].

Allium victorialis, which is known locally as Caucas or Japanese Allium, has its roots from Hokkaido, the northern part of Japan. It is one of the Allium species that have been understudied but few types of research have concluded on Caucas' ability to act as an antithrombotic, thus, preventing blood clots [28].

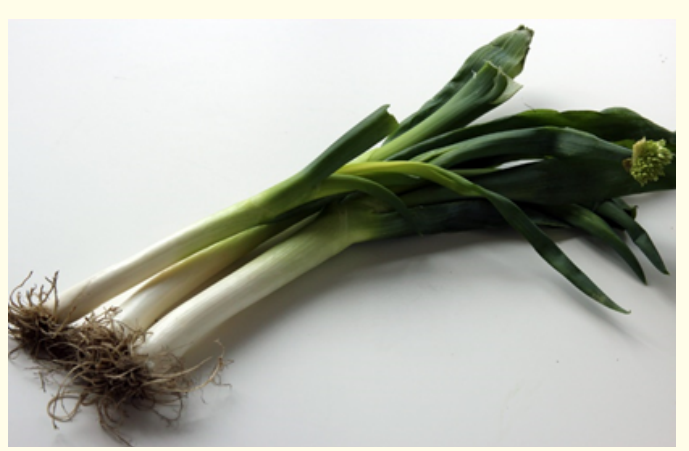

Figure 9: Welsh onion (alsagarden.com).

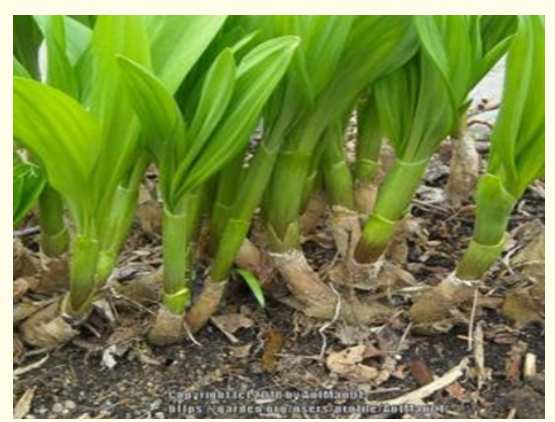

Figure 10: Japanese allium (caucas).

Allium porrum is another species of the Allium genus and it's also a type of leek, which is highly patronized because of its palatability and medicinal effect on mankind. It is principally grown in Serbia. In recent research, the total phenolic, antioxidant and antibacterial effect of the leek was determined and concluded to be a potent source of antioxidant [28].

Allium mongolicum regel is a long-existing plant, which belongs to the Allium family. It is a very useful Mongolia medicinal herb and is also widely used in the western part of China. The Allium mongolicum regel is used in the kitchen as a seasoning to enhance the deliciousness of their meals and also for the health benefit. Found on the medicinal record of Mongolia is Allium mongolicum's ability to lower blood pressure, lower blood cholesterol, stimulate appetite, replenish the kidney and also serve as an aphrodisiac and anti-inflammation [29].

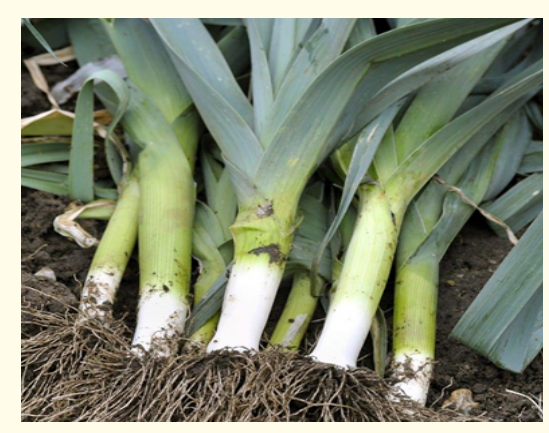

Figure 11: Allium porrum (leek). 


\section{Organosulfur compounds of allium species}

Organosulfur compounds are a special type of plant chemicals found mostly in Allium species. They are compounds that have a sulfur atom attached to a cyanate group or a carbon atom in a cyclic or non-cyclic configuration [30]. Most of the biological and pharmacological benefit that Allium species exerts from its consumption is attributed to its organosulfur compounds which are also the cause of the pungent smell of most Allium species especially garlic. The smell of Allium species is attributed to the s-alk (en) yl -L-cysteine sulfoxide within the vacuoles of its cells. When the vacuoles are crushed by way of chewing or cooking, the cysteine sulfoxide is destroyed enzymatically to sulfenic acid, which decays suddenly to thiosulfate. Thiosulfinates themselves are unstable and they decay to a complete mixture of compounds. The products of the decomposition which emits the pungent smell are diallyl sufide, diallyl disulfide, diallyl trisulfide and diallyl tetrasulfide [31]. Organosulfur compounds can be toxic when taken in excess amount but can be therapeutic when taken in moderation by increasing the activities of enzyme that protect against oxidation. Principally, there are two groups of vegetables that contain the organosulfur groups. The first group of vegetables is the Allium species of the Amaryllidaceae family which contains s-alk (en) yl-L-cysteine sulfoxide whiles the second group is those that belong to the eruca genus of the Brusicca family containing s-methyl cysteine -L- sulfoxide [32]. Several types of research have been done that show positive evidence of Allium species consumption and reduced risk of diseases. The mechanism is that organosulphur compounds help in limiting reactive oxygen species levels by hindering nicotinamide adenine dinucleotide phosphate (NADPH) oxidase, which is a reactive oxygen species generator. Organosulfur compounds also help to prevent the degradation of antioxidant enzymes such as glutathione s-transferase. Other studies have also shown how organosulfur compounds reduce risk of cardiovascular diseases such as hypertension by acting as an angiotensin-converting enzyme (ACE) inhibitor with the corresponding increase in dilation of blood vessels and decreasing of resistance and also prevent thrombosis by the inhibition of cyclooxygenase HMG-CoA and platelet aggregation [29]. Nitric oxide secreted by vascular endothelium is needed to maintain cardiovascular homeostasis. Oganosulfur compounds can increase the availability of the nitric oxide by increasing the expression of endothelial nitric oxide synthase [30].

Allium cepa (onion), which is cultivated throughout the world and not only known for its edible values but also for its medicinal properties mainly contains flavonoids, a sulfur-containing compound, phenolic acids, cepaenes and anthocyanins. Other species of the Allium that share similar features with the Allium cepa (onion) are Allium fistulosum (Japanese bunching onion), Allium proliferum (Egyptian onion) and Allium canadense (Canada onion) [26]. A high-performance liquid chromatography analysis shows that onion has more flavonoids than organosulfur compounds with over 50 flavonoids and 25 flavonols characterized and quercetin glycosyl derivatives been the most significant groups. Red onions contain approximately $1917 \mathrm{mg}$ of flavonol per kilogram of fresh weight whiles yellowish onion contains approximately $1187 \mathrm{mg}$ of flavonol per kilogram of fresh weight [27].
Allium sativum (garlic) is also among the commonest Allium species that is almost produced all over the world known for its edible and medicinal values. Apart from organosulfur compounds that dominate in garlic, it, however, contains flavonoids, steroidal saponins and phytosterol. The dominant organosulfur compound that exists in garlic is allicin however there are other compounds such as alliin, methiin, propii, and isoalliin [27]. The conversion of alliin into allicin by the enzyme alliinase forms new organosulfur compounds called ajoene [29]. The table below elaborates on the different types of organosulfur compounds and their structures present in Allium species.

\begin{tabular}{|c|c|c|}
\hline $\begin{array}{l}\text { Organosulfur } \\
\text { Compound }\end{array}$ & Structure & References \\
\hline Alliin & & [36] \\
\hline Allicin & & [36] \\
\hline Ajoene & & [36] \\
\hline Captopril & & [36] \\
\hline $\begin{array}{l}\text { S-allyl-mercapto- } \\
\text { captopril }\end{array}$ & & [36] \\
\hline $\begin{array}{l}\text { S-allylmercapto- } \\
\text { cysteine }\end{array}$ & & [36] \\
\hline $\mathrm{N}$-Acetylcysteine & & [36] \\
\hline S- ethylcysteine & & [36] \\
\hline
\end{tabular}




\begin{tabular}{|c|c|c|}
\hline Diallyl disulfide & & [36] \\
\hline S-allyl-L-Cysteine & & [36] \\
\hline Cycloalliin & & [37] \\
\hline $\begin{array}{l}\text { S-alkyl-L-cyste- } \\
\text { ine sulfoxide }\end{array}$ & 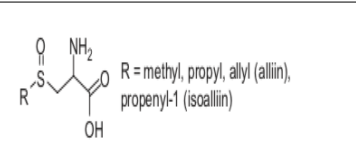 & [37] \\
\hline $\begin{array}{l}\text { Mono-, di-, and } \\
\text { trisulfides }\end{array}$ & 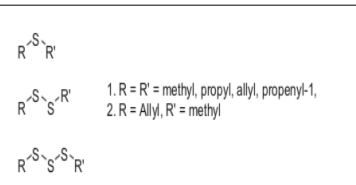 & [37] \\
\hline Thiosulfonate & 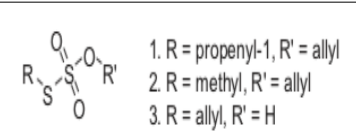 & [37] \\
\hline S- alkylcysteine & $\begin{array}{ll}R^{\prime} \backslash N H & 1, R=\text { alky, } R^{\prime}=\text { gutamyl } \\
& 2 \cdot R=a l y, R^{\prime}=H\end{array}$ & [37] \\
\hline $\begin{array}{l}\text { Cysteine alkyl } \\
\text { disulfide }\end{array}$ & $\mathrm{R}_{\mathrm{S}}{ }^{\mathrm{S}} \mathrm{Y}_{\mathrm{OH}}^{\mathrm{O}}$ & [37] \\
\hline
\end{tabular}

Table 1: Organosulfur compounds and their structures and sources.

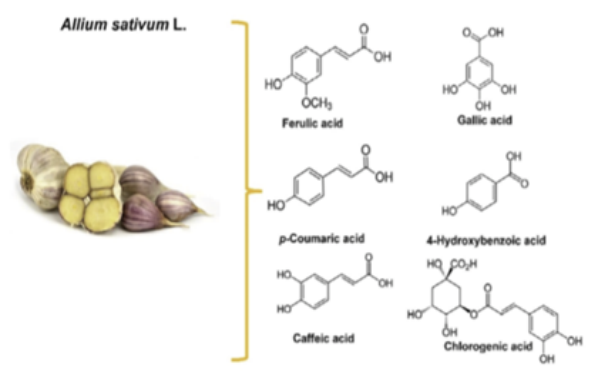

Figure 12: Some polyphenols with their structures that exist in Allium sativum (garlic).

Extraction of dietary PSs from allium species and their wastes, purification, and isolation

Today's pursuit of health and medicinal products has led to the production of extracts from vegetables both in industry and in academia for research purposes. There are many extraction methods that have been developed to extract dietary polysaccharides. Among these are solvent, hydro distillation, liquid-liquid, solid phase, supercritical fluid, pressurized liquid, pulse electric, enzyme assisted, microwave-assisted, ultrasound-assisted, and high voltage electrical discharge extraction methods [38].

Solvent extraction of solid substrates, which is also known as solid-liquid extraction, is one of the oldest sample preparations for solid substances. It serves not only to isolate targeted molecules of a particular insoluble high molecular weight fractions but also other compounds that could hamper with subsequent steps of the analytical process. Von Soxhlet in 1879 developed the conventional soxhlet extraction technique, which has up to date been used widely as a standard technique, and its method has remained the primary reference against a new solvent extraction method. The weaknesses of the technique led to the development of a new extraction method but the main motive behind the development of the soxhlet technique was to isolate fat from milk [39].

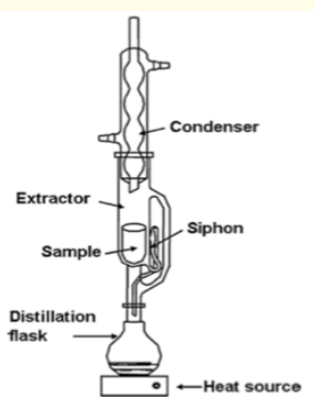

Figure 13: Conventional soxhlet extraction apparatus.

In the soxhlet extraction technique, the sample is placed in a thimble holder that is progressively filled with condensed fresh solvent from a distillation flask. When the liquid reaches the overflow level, a siphon aspirates the solute of the thimble holder and uploads it back into the distillation flask, carrying the extracted analytes into the bulk liquid. This process is repeated several times until completed extraction is achieved [38]. Despite it's been outdated, it still has some advantages over the modern extraction techniques. The repetition of the process always brings the sample into contact with fresh extractant or solvent, which facilitates the displacement of transfer equilibrium. Also, no filtration is required after leaching and finally, equipment is not expensive [37]. In a recent study in 2017, Kodal and Aksu used the conventional soxhlet technique to extract phenolic from waste orange peels at a very lower cost and they achieved a high yield of $57.3 \%$, thus, $0.57 \mathrm{~g}$ phenolic pigments per gram dry peel [39]. Another extraction technique that was established since the 1990's but has rarely been used in recent years is Pressurized liquid extraction or accelerated solvent extraction. Pressurize liquid extraction or accelerated solvent extraction is an extraction technique that involves the extraction of bioactive compounds using liquid solvent at a very high temperature and pressure which enhance the extraction performance to produce high solubility and high diffusion rate as compared to those done under room temperature and normal atmospheric pressure. In pressurized solvent extraction, the stainless steel extraction cell is filled with a solid sample and a suitable solvent is used under a high temperature of about 40 to $200^{\circ} \mathrm{C}$ and pressure between 500 to 3000 p.s.i for a short period of time usu- 
ally between 5 - 15 minutes. With the aid of compressed gas, the sample extract is collected in a Vial [40]. The diagram below is the schematic set-up of pressurized liquid extraction [40].

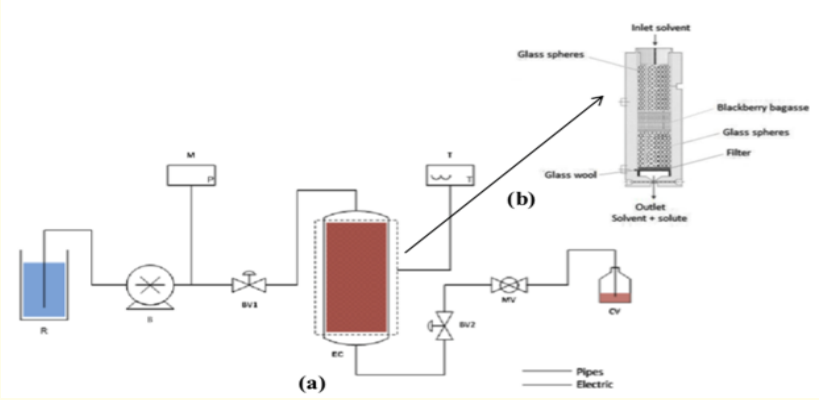

Figure 14: Pressurized liquid extraction schematic diagram. (R) Solvent reservoir (B) Solvent pump (M) pressure gauge (BV1 and BV2) block valves (EC) extraction cells with heating jacket (MV) micrometr valve $(\mathrm{T})$ temperature controller and indicator (CV)

Collection vessel.

The use of ultrasound in extracting samples can be completed in minutes with simplicity, high reproducibility, reducing the consumption of solvent, giving higher purity to final products, eliminating post-treatment of waste and consuming only a fraction of fossil energy that is normally used in conventional soxhlet extraction method. The sound wave which is above the hearing of the human ear (1-16Khz) is known as ultrasound, that is, waves with the frequency of $20 \mathrm{Khz}$ and above. A medium such as solid, liquid or gas is required for its propagation which involves a series of expansion cycle to create bubbles and when the power is maintained or increase, the negative pressure exerted exceeds the local tensile strength of the sample so it burst to release its content for analysis. There are different types of ultrasonic generators and the diagram below gives the pictorial view the types [41].

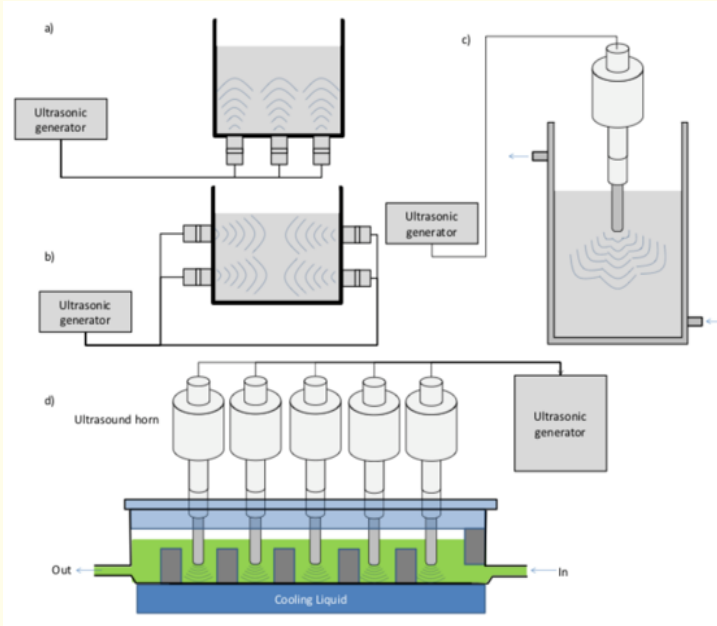

Figure 15: Types of ultrasonic assisted instruments a and $\mathrm{b}=$ ultrasonic bath, $\mathrm{c}=$ ultrasonic horn, $\mathrm{d}=$ continuous ultrasonic horn based extraction unit.
There is evidence of numerous researches that have proofed that the ultrasound-assisted extraction technique improves extract yield of products compared to the conventional extraction method [43].

Microwave-assisted extraction is another modern technique that has also been proven to increase the yield of products. It is a process of using microwave energy to heat solvent in contact with a sample in other to separate analytes from the sample matrix into the solvent. Microwaves are nonionizing electromagnetic energy with a frequency from 0.3 to $300 \mathrm{GHz}$. The energy is transmitted as waves, which can penetrate biological materials such as species of Allium and interact with the polar molecules inside the material to generate heat [40]. The working principle is based on the ability of a polar chemical compound to absorb microwave energy according to its dielectric constant. The absorbed energy is proportional to the medium's dielectric constant resulting in dipole rotation in an electric field and migration of ionic species. The ionic migration generates heat as a result of resistance of the medium to the ion flow causing a collision between molecules [42]. A report used the microwave extraction technique to successfully extract pectin polysaccharides from waste mango peels and the optimum condition of the microwave techniques that produced maximum yield was when the microwave power was $413 \mathrm{~W}$, $\mathrm{pH}$ of 2.7 and time of 134 seconds [44]. Microwave extraction also promoted extraction yield of Chlorella sorokiniana by 15 times, 100 percent of Nannochloropsis Satina and over 10 times per Galdiera Sulphuraria when compared with the conventional solvent extraction method [39].

Enzyme assisted extraction has also been deemed as a substitute method for improving the yield of substance. It involves the use of hydrolytic enzymes such as cellulase, hemicellulase, xylanase etc. to breakdown the cell wall, which is predominate, made of high complex polymers such as cellulose, hemicellulose, lignin and pectin. Enzyme assisted extraction has recently been successfully used to extract polyphenols from edible lotus, Laurus nobilis L. (bay leaves) and Momordica balsamina L. fruit [44].

Supercritical water extraction technique has also been used for several years to extract many volatile compounds such as essential oils and aromatic compounds from substances for either industrial or academic purposes. A liquid is said to become supercritical when the temperature and pressure are increased above the critical point. There are numerous supercritical fluids that can be used in this technique but most frequently Carbon dioxide $\left(\mathrm{CO}_{2}\right)$ is used because of its low toxicity, low critical temperature and pressure, high diffusivity combined with high solvent strength and wide applicability. For $\mathrm{CO}_{2}$, the supercritical point occurs at a temperature of $31^{\circ} \mathrm{C}$ and at a pressure of 72 bar. The basic principle is that supercritical fluid, which is mostly $\mathrm{CO}_{2}$, is passed through a vessel filled with sample, and further applies pressure in the process in other to collect the extracted component. The sample vessel is placed in an oven to control the temperature. The Supercritical fluid extraction instruments consist of high-pressure pumps for delivery of supercritical fluid, a high-pressure vessel for holding 
the sample, a restrictor and a collection device. The diagram below shows the schematic set-up of the Supercritical fluid extraction technique [45].

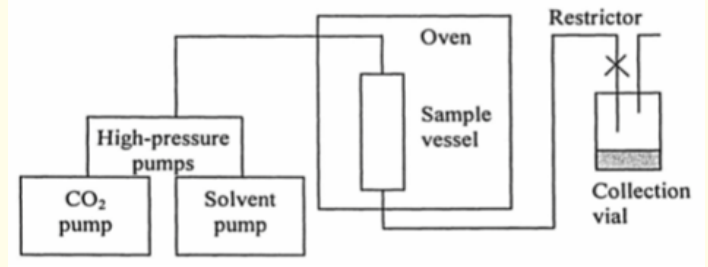

Figure 16: Schematic setup of Supercritical fluid extraction.

When using Supercritical fluid extraction method to extract oil from muskmelon seed, Maran and Priya (2015) found out that optimum yield of $48.11 \%$ was achieved when pressure was $44 \mathrm{MPa}$, $49^{\circ} \mathrm{C}$ of temperature, $0.64 \mathrm{~g} / \mathrm{min}$ of $\mathrm{CO}_{2}$ flow rate and 81 minutes extraction time.

Pulse electric field and moderate electric field extraction technique is another modern method but it is rarely used in industries but few types of research have adopted this method to improve extraction yield. In this technique, alternating electric fields are used to enhance cell membrane permeability and soluble matter diffusion from various plant materials. The insertion of a pair of a direct powdered metal electrode into the solution possible allows for the dissolution of the electrode's substance or the heavy metal ion into the sample [46]. The diagram below is the schematic set-up of the pulsed electric field gadget. The device has many peripherals and they are as follows; (1) power source, (2) constant temperature circulating water bath, (3) ferrite o-core, (4) glass spiral tube, (5) primary coil, (6) solvent inlet, (7) glass chamber, (8) sample inlet, (9) jacket shell and (10) sand filter.

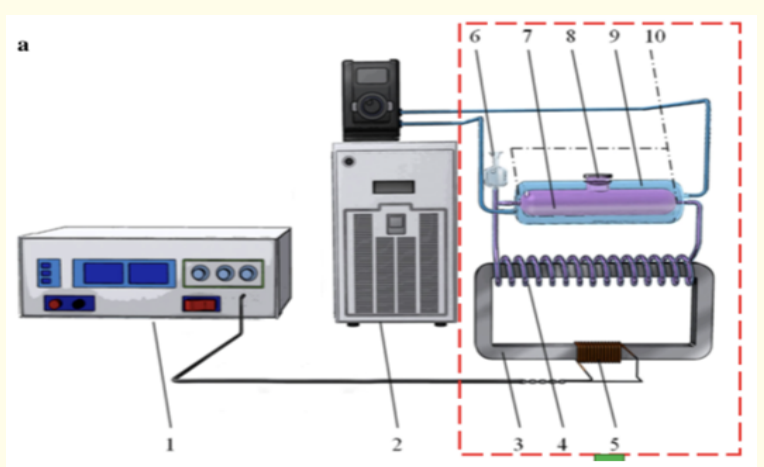

Figure 17: Schematic diagram of pulse electric field setup.

Researches have been conducted using the pulse electric field method to extract various extractant from biological substances. Puértolas., et al. (2013) used the pulse electric filed method to extract anthocyanin from fresh potato and by using the response surface methodology, he found out that PEF treatment of $3.4 \mathrm{kV} / \mathrm{cm}$ and 105 microsecond resulted in the highest disintegration index from lowest specific energy requirement $(8.92 \mathrm{kj} / \mathrm{kg})$ which led to an increase in the extraction yield of anthocyanin [47].

\begin{tabular}{|c|c|c|c|c|c|c|}
\hline $\begin{array}{l}\text { Extraction } \\
\text { method }\end{array}$ & $\begin{array}{l}\text { Soxhlet } \\
\text { extraction }\end{array}$ & $\begin{array}{l}\text { Ultrasound- } \\
\text { assisted } \\
\text { extraction }\end{array}$ & $\begin{array}{c}\text { Subcritical water } \\
\text { extraction }\end{array}$ & $\begin{array}{l}\text { Microwave- } \\
\text { assisted } \\
\text { extraction }\end{array}$ & $\begin{array}{c}\text { Enzyme assisted } \\
\text { extraction }\end{array}$ & $\begin{array}{c}\text { Electric field assisted } \\
\text { extraction }\end{array}$ \\
\hline $\begin{array}{l}\text { Basic } \\
\text { description }\end{array}$ & $\begin{array}{l}\text { The sample is } \\
\text { placed in a glass } \\
\text { fiber thimble and } \\
\text { by using a soxhlet } \\
\text { extractor; the sam- } \\
\text { ple is repeatedly } \\
\text { infiltrated with } \\
\text { condensed vapors } \\
\text { of the solvent. }\end{array}$ & $\begin{array}{l}\text { The sample is } \\
\text { immersed in } \\
\text { a solvent in } \\
\text { a vessel and } \\
\text { placed in an } \\
\text { ultrasonic bath }\end{array}$ & $\begin{array}{l}\text { A sample is loaded } \\
\text { in a high-pressure } \\
\text { vessel and extracted } \\
\text { with subcritical fluid } \\
\text { usually } \mathrm{CO}_{2} \text { at a pres- } \\
\text { sure between } 150 \text { to } \\
450 \text { bar and tempera- } \\
\text { ture } 40-150^{\circ} \mathrm{C} \text {. }\end{array}$ & \begin{tabular}{|} 
A sample is \\
immersed in \\
a microwave \\
absorbing \\
solvent in a \\
closed vessel \\
and irradiated \\
with microwave \\
energy
\end{tabular} & $\begin{array}{l}\text { Involves the use } \\
\text { of an enzyme to } \\
\text { breakdown the } \\
\text { cell wall of the } \\
\text { biomolecules }\end{array}$ & $\begin{array}{l}\text { Involves the use of the } \\
\text { alternating electric } \\
\text { field to enhance cell } \\
\text { membrane permeabil- } \\
\text { ity and soluble matter } \\
\text { diffusion from various } \\
\text { plant material }\end{array}$ \\
\hline $\begin{array}{l}\text { Extraction } \\
\text { time }\end{array}$ & $3-48$ hours & $10-60 \min$ & $10-60 \min$ & $3-30$ min & $2-3$ hours & 5-6 hours \\
\hline Sample size & 1 - 3 grams & $1-30 \mathrm{~g}$ & $1-5 g$ & $1-10 \mathrm{~g}$ & $2-5 g$ & $10-15 g$ \\
\hline Solvent usage & $100-500 \mathrm{ml}$ & $30-200 \mathrm{ml}$ & $2-5 \mathrm{ml}$ & $10-40 \mathrm{ml}$ & $10-50 \mathrm{ml}$ & $15-150 \mathrm{ml}$ \\
\hline Investment & Low & Low & High & Moderate & Moderate & Moderate \\
\hline Advantages & $\begin{array}{l}\text { No filtration } \\
\text { required. }\end{array}$ & $\begin{array}{l}\text { Multiple } \\
\text { extractions }\end{array}$ & $\begin{array}{l}\text { Fast extractio } \\
\text { Minimal solvent }\end{array}$ & $\begin{array}{l}\text { Fast and } \\
\text { multiple ex- } \\
\text { tractions, low } \\
\text { solvent }\end{array}$ & $\begin{array}{l}\text { Improves recov- } \\
\text { ery of compound } \\
\text { whiles preserv- } \\
\text { ing functional } \\
\text { properties }\end{array}$ & $\begin{array}{l}\text { No heating of } \\
\text { substances and low } \\
\text { chemical use. }\end{array}$ \\
\hline Disadvantage & $\begin{array}{l}\text { Long extraction } \\
\text { time and large } \\
\text { solvent volume }\end{array}$ & $\begin{array}{c}\text { Repeated } \\
\text { extraction may } \\
\text { be required. }\end{array}$ & $\begin{array}{c}\text { Many parameters to } \\
\text { optimize }\end{array}$ & $\begin{array}{l}\text { The solvent } \\
\text { must be able to } \\
\text { absorb micro- } \\
\text { wave }\end{array}$ & $\begin{array}{l}\text { It requires much } \\
\text { time }\end{array}$ & $\begin{array}{l}\text { Sudden power cut may } \\
\text { after the process }\end{array}$ \\
\hline Reference: & {$[41]$} & [43] & {$[45]$} & [41] & [42] & [45] \\
\hline
\end{tabular}

Table 2: Comparison of the various extraction techniques. 
The aqueous extracts of samples are most of the time subjected to either ethanol, fractional or acidic precipitation with acetic acid to yield crude polysaccharide mixed with proteins and other pigments. For accuracy, the crude polysaccharides extracted are purified using series of combined technologies such as chemical or enzymatic treatment to remove proteins and other pigments, dialysis to remove different salts or small molecules, followed by either column chromatography or affinity chromatography, gel filtration chromatography before a pure polysaccharides can be obtained [46].

Zhang., et al. (2015) isolated both low and high molecular weight fructan from Aged garlic by subjecting the aged garlic to ultrafiltration with $3 \mathrm{kDa}$ membrane followed by dialysis of the retentate using $3.5 \mathrm{kDa}$ cut off dialysis membrane and ion-exchange chromatography and the flow-through pool represented high molecular weight fructan. The ultrafiltrate of the aged garlic was again subjected to Bio-Gel P-2 Chromatography and low molecular weight of less than 1800Da was found making the fructan a low molecular weight fructooligosaccharide. The isolation of low and high molecular weight fructan is demonstrated in the chart below [47].

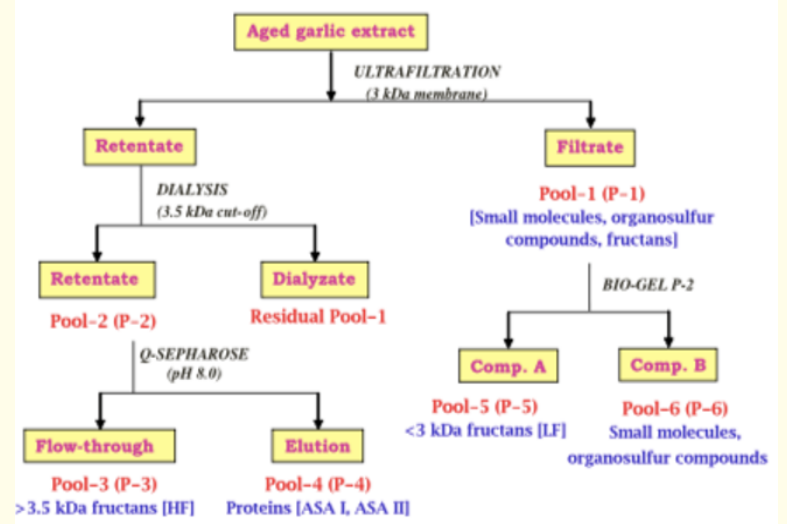

Figure 18: Flowchart of isolation of high molecular weight and low molecular weight fructans from aged garlic extract. ASAI, and ASAII denote garlic lectins present in both aged garlic extract and raw garlic extract.

Liu., et al. (2019) also isolated 40kDa molecular weight proteoglycan from Inonotus obliquus comprising of D-galactose, D-glucose, D-xylose and D-mannose [48].

\section{Physicochemical, structural and functional characteristics}

Polysaccharides obtained from Allium species differ far apart in terms of the chemical structure and physical properties. The physicochemical and structural characterization of polysaccharides are commonly defined by molecular weight, monosaccharide composition, configuration and position of glycosidic linkage, type and polymerization degree of branches, monosaccharide sequence, chain conformation, solubility, particle size and rheological properties [49]. Different Allium species polysaccharides with various chemical structures have been identified and their primary struc- tural features including molecular weight, monosaccharide composition, extraction and isolation method, chemical characteristics, bioactivity and their references are listed in the table below.

Different polysaccharides isolated from Allium species vary with the extraction method and source of raw materials and also polysaccharides isolated from different species of the Allium family with the same extraction method and purification processes do not show the same chemical composition, chemical structure, and molecular weight. Furthermore, polysaccharides belong to a structurally diverse class of macromolecules. The monosaccharide unit in polysaccharide can interconnect at several points to produce different branches or linear structures [21]. Chemical structures that often exist in polysaccharides of Allium species are fructan, inulintype fructan, levan type fructan, graminan type fructan, pectin, glucofructan, glycoprotein, etc. [35].

Chandrashekara and Venkatesh (2016) isolated fructan from aged garlic and both low and high molecular weight fructans were purified and the structure determined by H NMR and C NMR spectroscopy revealed that both have (2-1) $\beta$-D-fructofurannosyl bonds linked to terminal glucose at the non-reducing end and $\beta$-Dfructofurannosyl branching on its backbone.

The diagram below illustrates the different types of fructan from higher plants according to the classification of Van laere and Van den Ende (2002). There are five different fructans distinguished by glycosidic linkages. They are inulin, which occurs mostly in chicory and Jerusalem antichokes has 2-1 linkages between its fructosyl residues. The second type of fructan is levan, which also consists of 2-6 linked fructosyl units in linear arrangements. The third is the branched garminin fructans, which is often, found in wheat and has either a levan or inulin backbone with one or more short branches. The fourth fructan is the inulin neoseries, which are linear with 2-1 linkages but with glucose molecules between two fructosyl subunits. It has been found to be present in Onion and asparagus. Levan neoserie is the fifth type of fructan that has internal glucose molecule and linkage of 2-6 [42].

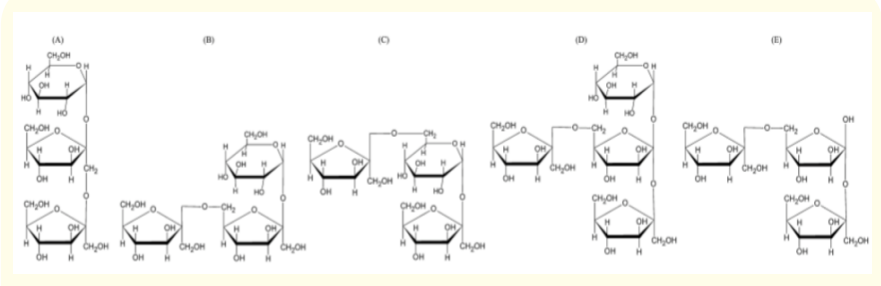

Figure 19: (A) Kestose (B) 6-Kestose (C) Neokestose (D)bifurcose (E) mix type F3 fructan.

Fructan biosynthesis is initiated when photosynthesis exceeds demand and sucrose reaches a critical level in sink organs. The diagram below describes the details of the processes that are involved [41]. 


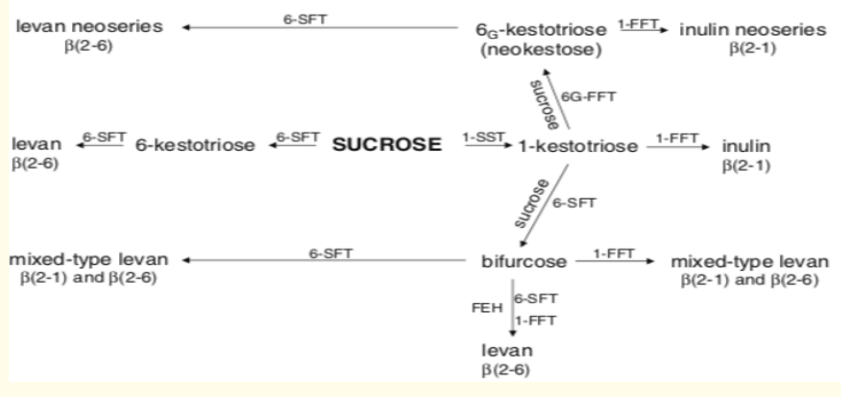

Figure 20: Proposed model for fructan biosynthesis (Livingston et. al., 2009).

Glucofructan was also isolated from Allium ampeloprasum var. porrum by hot water extraction method and purified by Sephacryl S-300 HR high-resolution chromatography. It was composed of Dfructose and D-glucose in the ratio of 10:6 respectively. The estimated weight-average mass was $2.6 \times 10^{3}$ and the structure was investigated by chemical and spectroscopic methods, including methylation analysis, nuclear magnetic resonance and electrospray mass spectrometry. The results yielded glucofructan structures as $\alpha{ }_{-}$-Fruf-(2-1)- $\beta-{ }_{D}$-Fruf-(2-1)- $\left\{\left[\quad \alpha_{-}-\right.\right.$Glcp-(1-6)- $\beta{ }_{-}$-Fruf-(2-6)]$\beta-{ }_{D}$-Fruf- $\left.(2-1)\right\} 4-\beta-{ }_{D}$-Fruf-(2-1)- $\alpha{ }_{-}-$Glcp [50].

Pectin polysaccharides, xyloglucan and little amount of hemicellulose-pectin complexes have been extracted from plant's cell wall by various methods including oxalate-citrate buffer, cyclohexanetrans-1,2 -diamine tetraacetate, and dilute alkali [45]. In a recent work that was done by Golovchenko., et al. (2012), he extracted pectin polysaccharides from Allium cepa with extraction yield of both plant raw material and parent polysaccharide fraction was $0.31 \%$ and $36 \%$ and molecular weight of $559 \mathrm{kDa}$ and $113 \mathrm{kDa}$ respectively and also a protein yield of $3.3 \%$. Monosaccharide composition carried out by gas chromatography reveals rhamnose, arabinose, galactose, xylose, and glucose [23].

\section{Biological benefits and applications in the food industry} Antimicrobial activities of allium species

Antimicrobial activities of garlic have been studied extensively over the past decade and it has been found that the main constituents of Allium species that fight or inhibit microbes are the sulfoxides. The chief of these sulfoxides is alliin from garlic and giant garlic, isoalliin from onion and shallot and methiin from chives and Chinese chives [21]. When an Allium species is first crushed, it contains thiosulfinates and when stored for a period of time different forms of compounds such as dialk(en)yl sulfides are revealed. When macerated in oil ajoene is formed and when heated at high-temperature heterocyclic sulfurs, allyl alcohol and 3-(allyltrisulfanyl)-2-aminopropanoic acid forms. Allicin which is found in Allium species principally garlic inhibit microorganism because of their -S (0)-S- group which reacts with the SH group of cellular proteins to generate mixed disulfides and further to cysteine sulfoxides which is believed to fight or prevent microorganism [33]. Allyl alcohol is also oxidized intracellularly to alkylating agents, which is a powerful microorganism inhibitor. Several studies have demonstrated an effect on some Allium species such as rosy garlic as antibacterial compounds against both gram-positive and gram-negative bacteria such as Enterococcus feacium, staphylococcus aureus, bacillus subtilis and Escherichia coli. Antifungal activities of volatile oils of Allium plants have exhibited success over Trichophyton rubrum, Trichophyton erinacei, and Trichophyton soudanense with a minimum inhibiting concentration of $64 \mathrm{ug} / \mathrm{ml}$. Several studies have also been conducted on the antiparasitic and antiviral properties of Allium species [20].

\section{Antioxidant and anti-inflammatory activities of Allium species}

Antioxidants are of significance when it comes to preventing oxidative stress and degenerative diseases. The protective effect is attributed to various antioxidant compounds such as vitamin $\mathrm{C}$ and E, Beta-carotene, polyphenols. Allium species are also a good source of antioxidants because of their richness in flavonoids which is a form of polyphenols [30]. There are countless researches that have presented the antioxidant properties of different kinds of Allium species. Antioxidant in Allium cepa conducted by Ma and friends have demonstrated incredible radical scavenging ability by scavenging ABTS radical cation by $97.52 \%$, $\mathrm{Fe} 2+$ chelating by $98.94 \%$, superoxide anion radical scavenging by $76.27 \%$, DPPH radical by $93.68 \%$, hydroxyl radical by $65.12 \%$, lipid peroxidation inhibiting by $86.43 \%$, and B-carotene bleaching inhibiting by $92.26 \%$ [27].

The reaction of free radicals with the body tissue could potentially lead to inflammatory which is characterized by calor, dolor, rubor, tumor, and penuria. Research has found that Allium sativum has the ability to modulate cytokines expression in the lipopolysaccharide activated human blood thereby inhibiting nuclear factor kappa light chain enhancer of activated B cell (NF-KB) which is a useful tool to prevent in inflammation. Allium flavum L. has also demonstrated anti-inflammatory potential by inhibiting cyclooxygenase - 1 (COX 1) and 12 lipoxygenases (12-LOX) which are all precursors of inflammation [32].

\section{Antitumor activities of Allium species}

Polysaccharides from Allium species have demonstrated tumorpreventing activities by firstly, preventing ontogenesis due to its richness in antioxidant and other tumor inhabitation compounds that have already been discussed in the previous pages. Secondly, by enhancing our immunity and lastly by induction of apoptosis to tumor cells and inhibiting tumor metastasis. The diagram below explains the proposed mechanism by which diallyl trisulfide works against carcinogenesis [49].

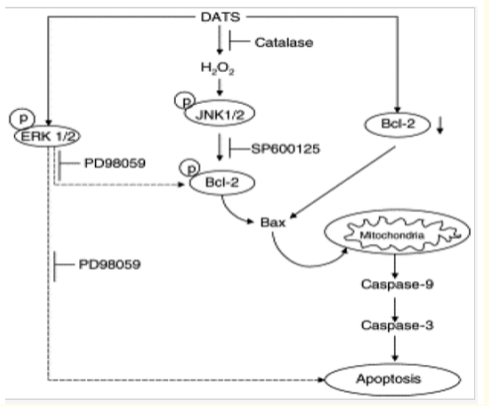

Figure 21: Proposed mechanisms by which diallyl trisulfide works against carcinogenesis. (DATS) diallyl trisulfide. 
There is currently the rising burden of cancer incidence in various organs worldwide and very effective therapies are needed urgently to control these malignancies that are consuming the human race. The use of chemotherapy medications has been the adopted mode of treatment in our hospitals but unfortunately tends to pose a negative side effect in the long-term with frequently reported symptoms of nausea, vomiting, hair loss, tiredness, sensory neuropathy and motor neuropathy. Luckily, there have been countless researches on the use of non-toxic biological macromolecules such as polysaccharides and polysaccharide-protein complexes to inhibit cancer cells or increasing the efficacy of conventional chemotherapy medications [41]. Zhanjun and his colleagues isolated and purified both neural and acidic polysaccharides from Allium macrostemon bung and both exhibited a strong antitumor potential against human gastric carcinoma cell BGC-823 with the acid polysaccharides exhibiting the highest inhibitory rate of $85.94 \%$ and the neutral polysaccharide exhibiting inhibitory rare of $52.63 \%$ [ 48].

\section{Cardiovascular disease and antidiabetic activities of Allium} Species

Cardiovascular as earlier discussed is the diseases related to the heart and the most common of all irrespective of age is hypertension. An in vivo and in vitro studies have demonstrated that organosulfur compounds such as s-allyl-cysteine and allicin are effective in curbing some pathophysiological factors in hypertension such as expression of nuclear factor-kB, oxidative stress, renin-angiotensin-aldosterone system and reduction in the bioavailability of nitric oxide [45]. Other studies have also attested to the fact that garlic consumption led to the lowering of blood pressure, prevention of atherosclerosis, reduction of serum cholesterol and triglyceride, inhibition of platelet aggregation, and increasing fibrinolytic activities [48].

Diabetes is also among the principal cause of death in both developed and developing countries and according to World Health Organization, about 347 million people suffer from diabetes and it has been projected that by 2030 diabetes will be the $7^{\text {th }}$ cause of death. In a Meta study that was done by Emami, he found out that garlic consumption reduced the fasting blood glucose in comparison to those who took garlic supplements and didn't even take garlic at all [48]. The mechanism has always been attributed to its organosulfur compounds such as alliin, allicin, allyl disulfide, allyl trisulfide, s-allyl cysteine, ajoene, and allyl mercaptan. These compounds have been found to reduce insulin resistance and increase insulin sensitivity [25].

Renoprotective, hepatoprotective, and hematological effect of allium species

Renal failure occurs when the kidney is no more able to function or do its duties as it is expected to do normally. Mice studies have been done to ascertain the effectiveness of Chinese chives in protecting the liver. A $200 \mathrm{mg} / \mathrm{kg} /$ day Chinese chives polysaccharides were given to adenine induces mice (chronic kidney failure mice) and the pathological damage reduced by $59.2 \%$ and the levels of serum creatinine and serum blood urea nitrogen also decreased by $23.9 \%$ and $34.7 \%$ compared to the model group [25].
Chronic liver failure is an increasingly recognized malice, which encompasses deterioration of the liver function in patients with cirrhosis causing the failure of one or two organs at a high mortality rate. Garlic has been able to improve the liver function of rats that were fed with $200 \mathrm{~g} / \mathrm{kg} /$ day and there was a significant reduction in their ALT, ALP, and PCV whiles AST and hemoglobin increased significantly [21].

\section{Effects of pre- and post-harvest conditions on polysaccha-} rides

Pre-harvest conditions

Many factors can affect the chemical composition of garlic in the production process and therefore the optimization of the growing conditions can lead to enhancement in the quality of the bioactive molecules or properties of the final product. Such factors include; irrigation, genotype, and fertilization. Much studies have not elicited the effect of soil moisture on the properties of garlic but csiszar and his friends in their paper stated that a soil moisture of less than $40 \%$ could reduce the antioxidant properties, antioxidant enzyme activities such as catalase, glutathione reductase, glutathione transferase, peroxidase and superoxide dismutase. Based on the market needs and climate conditions, it is prudent to select the best cultivar to meet the need because the cultivar type can have an impact on the chemical composition as well. 103 cloves of garlic cloves was collected in some parts of the world by Hirata and their chemical compositions including S-allyl-cysteine sulfoxides and total phenolic was assessed but there were variations in each of the garlic cloves so it was concluded that the variations were as a result of the adaptability of the species in various environmental conditions during the expansion and dispersion process of the garlic cultivation throughout the world as a means of survival to the various unfavorable conditions [27]. Garlic like any other crops demands fertilizer for maximum yields. The application of $92 \mathrm{~kg} / \mathrm{Ha}$ of Nitrogen, $40 \mathrm{~kg} / \mathrm{Ha}$ of phosphorous and $30 \mathrm{~kg} / \mathrm{Ha}$ of potassium is recommended to achieve maximum yield of garlic bulb [30].

\section{Post-harvest conditions}

After harvesting of Allium species, they can be subjected to several biotechnological processes to ensure its longevity or shelf life or to improve its efficacy and bioavailability. In the case of garlic, its health benefits are as a result of the synergistic effect of its bioactive compounds. Unfortunately, some preservative processes such as soaking the bulb of the garlic in various solvents such as alcohol; wine, vinegar and applying heat at a high temperature end up reducing the thiosulfate content and antioxidant activities [34]. Black garlic is garlic that has been fermented and after the study, they found out that fresh garlic exhibited stronger immunomodulatory activity than black garlic, and also it was found out that the fructan quality and quantity in the black garlic degraded during the fermentation process and hence no immunomodulatory activity could be found in the black garlic [42].

Aged garlic is another product of garlic most people have decided to opt for because it has less smell as compared to raw garlic. Aged garlic is garlic that has been incubated for approximately 20 months in about $25 \%$ of ethanol at ambient temperature [45]. In 
Rye and Kang's study, they also compared the bioactive compounds and biological activities of fresh garlic to aged garlic and they concluded that aged garlic shows lower anti-inflammatory, anti-coagulatory, immunomodulatory and anti-allergic effect [47].

However, Gao's study on selenylated garlic polysaccharides shown contrary results from black and aged garlic as earlier on presented. Selenium polysaccharide is one of the organic selenium compounds which possesses duple and higher biological activities in comparison with polysaccharide and selenium only and it's more bioavailable to human. Their results showed that selenylated polysaccharides significant increase immune-enhancing activity of garlic polysaccharides in-vivo and Nitric acid - sodium selenite method is the best method for selenylating garlic polysaccharides for better results [48].

\begin{tabular}{|c|c|c|c|c|c|c|c|}
\hline $\begin{array}{l}\text { Plant } \\
\text { organ }\end{array}$ & $\begin{array}{c}\text { Extraction } \\
\text { method }\end{array}$ & $\begin{array}{l}\text { Extraction conditions } \\
\text { and yield } \\
\end{array}$ & $\begin{array}{l}\text { Monosaccharide } \\
\text { composition }\end{array}$ & $\begin{array}{c}\text { Molecular } \\
\text { weight }\end{array}$ & $\begin{array}{c}\text { Chemical } \\
\text { characteristics }\end{array}$ & Bioactivities & References \\
\hline Straw & $\begin{array}{l}\text { Hot water } \\
\text { extraction }\end{array}$ & $\begin{array}{l}\text { Temperature } 90^{\circ} \mathrm{C} \text {, time } 30 \mathrm{~min} \text {, } \\
\text { maximum extraction yield } 15 \%\end{array}$ & $\begin{array}{l}\text { Glucose, mannose, } \\
\text { galactose, xylose }\end{array}$ & -- & $\beta$ glycosidic bond & $\begin{array}{c}\text { Antioxidant, } \\
\text { antimicrobial }\end{array}$ & $\begin{array}{l}\text { Kellel., et al. } \\
\quad \text { (2015) }\end{array}$ \\
\hline Bulb & $\begin{array}{l}\text { Cellulose } \\
\text { assisted } \\
\text { extraction }\end{array}$ & $\begin{array}{l}\text { Temperature } 45^{\circ} \mathrm{C} \text {, time } 80 \mathrm{~min} \text {, } \\
\text { maximum extraction yield } 35.35 \%\end{array}$ & - & - & - & Antioxiant & $\begin{array}{l}\text { Pan and } \mathrm{Wu} \\
(2014)\end{array}$ \\
\hline Bulb & $\begin{array}{l}\text { Hot water } \\
\text { extraction }\end{array}$ & $\begin{array}{l}\text { Temperature } 21^{\circ} \mathrm{C} \text {, time } 30 \mathrm{~min}, \\
\text { extraction yield } 29 \%\end{array}$ & $\begin{array}{l}\text { Fructose, glucose } \\
\text { and galactose }\end{array}$ & $7.37 \mathrm{kDa}$ & $\beta$ glycosidic bond & Antioxiant & \\
\hline
\end{tabular}

Table 3: Extraction, physicochemical and structural characteristics, and bioactivities of PSs from garlic (Allium sativum L.).

\begin{tabular}{|c|c|c|c|c|c|c|c|}
\hline $\begin{array}{l}\text { Plant } \\
\text { organ }\end{array}$ & $\begin{array}{c}\text { Extraction } \\
\text { method }\end{array}$ & $\begin{array}{c}\text { Extraction conditions } \\
\text { a/nd yield }\end{array}$ & $\begin{array}{l}\text { Monosaccharide } \\
\text { composition }\end{array}$ & $\begin{array}{c}\text { Molecular } \\
\text { weight }\end{array}$ & $\begin{array}{c}\text { Chemical } \\
\text { characteristics }\end{array}$ & Bioactivities & References \\
\hline Bulb & $\begin{array}{c}\text { Solvent } \\
\text { extraction }\end{array}$ & $\begin{array}{c}\text { Temperature } 70^{\circ} \mathrm{C} \text {, time } \\
60 \mathrm{~min} \text {, extraction yield } \\
89.92 \% \\
\end{array}$ & $\begin{array}{l}\text { Rhamnose, arabinose, } \\
\text { xylose, mannose, } \\
\text { galactose, glucose }\end{array}$ & $7.02 \mathrm{kDa}$ & $\beta$ glycosidic bond & Antioxidant & $\begin{array}{l}\text { Zhu., et al. } \\
\text { (2017) }\end{array}$ \\
\hline Skin & $\begin{array}{l}\text { Microwave } \\
\text { assisted } \\
\text { extraction }\end{array}$ & $\begin{array}{l}\text { Temperature of } 40^{\circ} \mathrm{C} \text {, } \\
5700 \text { psi, time } 2.5 \mathrm{hrs}\end{array}$ & - & - & - & Antiodiants & $\begin{array}{l}\text { Huma., et al, } \\
\text { (2011) }\end{array}$ \\
\hline
\end{tabular}

Table 4: Extraction, physicochemical and structural characteristics, and bioactivities of PSs from onion (Allium cepa L.).

\begin{tabular}{|c|c|c|c|c|c|c|c|}
\hline $\begin{array}{l}\text { Allium } \\
\text { species }\end{array}$ & $\begin{array}{c}\text { Extraction } \\
\text { method }\end{array}$ & $\begin{array}{c}\text { Extraction conditions } \\
\text { and yield }\end{array}$ & $\begin{array}{c}\text { Monosaccharide } \\
\text { composition }\end{array}$ & $\begin{array}{c}\text { Molecular } \\
\text { weight }\end{array}$ & $\begin{array}{c}\text { Chemical } \\
\text { characteristics }\end{array}$ & Bioactivities & References \\
\hline $\begin{array}{l}\text { Allium } \\
\text { tuberosum }\end{array}$ & $\begin{array}{l}\text { Ultrasound } \\
\text { assisted } \\
\text { extraction }\end{array}$ & $\begin{array}{c}\text { Temperature } 37^{\circ} \mathrm{C} \text {, Ultrasound } \\
\text { power } 482 \mathrm{~W} \text {, time } 30 \text { min, solid } \\
\text { to liquid ratio } 1: 32 \text {, extraction } \\
\text { yield } 3.66 \%\end{array}$ & $\begin{array}{l}\text { Mannose, galac- } \\
\text { tose, glucose }\end{array}$ & $\begin{array}{c}8.83 \mathrm{kDa} \text {, } \\
3.5 \mathrm{kDa} \text {, and } \\
4.9 \mathrm{kDa}\end{array}$ & $\begin{array}{l}(1-3,6),(1-6) \\
\text { and } \\
1-) \text { glycosidic } \\
\text { bond }\end{array}$ & $\begin{array}{l}\text { Antioxidant } \\
\text { property }\end{array}$ & $\begin{array}{l}\text { Zhang., et al. } \\
\quad \text { (2016) }\end{array}$ \\
\hline $\begin{array}{l}\text { Allium } \\
\text { fistulosum }\end{array}$ & $\begin{array}{c}\text { Solvent } \\
\text { extraction }\end{array}$ & $\begin{array}{l}\text { Temperature } 90^{\circ} \mathrm{C} \text {, time } 60 \mathrm{~min}, \\
\text { extraction yield } 21 \%\end{array}$ & Fructose, glucose & $\begin{array}{l}1.5 \mathrm{kDa} \text { and } \\
1.18 \mathrm{kDa}\end{array}$ & $\begin{array}{c}\text { Terminal } \\
(21 \%), 2,1 \\
\text { linked } \beta \text {-D-Fruf } \\
\text { and } \beta \text {-D-Glcp }\end{array}$ & Antiviral & $\begin{array}{l}\text { Lee., et al. } \\
\text { (2012) }\end{array}$ \\
\hline $\begin{array}{l}\text { Allium } \\
\text { porrum }\end{array}$ & $\begin{array}{l}\text { Solvent } \\
\text { extraction }\end{array}$ & $\begin{array}{c}\text { Temperature } 65^{\circ} \mathrm{C} \text {, time } 65 \mathrm{~min} \\
\text { extraction yield } 51 \% \text { ( acid } \\
\text { as solvent) } 29 \% \text { (water as } \\
\text { solvent) }\end{array}$ & \begin{tabular}{|c|} 
Rhamnose, \\
ribose, arabinose, \\
xylose, mannose, \\
galactose, glu- \\
cose, GalA, GluA
\end{tabular} & $\begin{array}{l}1.1 \times 10^{6} \mathrm{Da} \\
9.5 \times 10^{5} \mathrm{DA}\end{array}$ & $\begin{array}{l}(1-3,6)- \\
\beta \text {-galactan, } \\
\text { Galacturonic } \\
\text { acid }\end{array}$ & $\begin{array}{l}\text { Stimulate } \\
\text { immune } \\
\text { system, }\end{array}$ & $\begin{array}{l}\text { Kratcha- } \\
\text { nova et. al., } \\
(2010)\end{array}$ \\
\hline $\begin{array}{l}\text { Allium } \\
\text { sativum }\end{array}$ & $\begin{array}{l}\text { Electric } \\
\text { field as- } \\
\text { sisted } \\
\text { extraction } \\
\text { method }\end{array}$ & $\begin{array}{c}\text { Temperature } 55^{\circ} \mathrm{C} \text {, time } 60 \\
\text { min, solid -liquid ratio } 1: 20 \text {, } \\
\text { excitation voltage } 200 \mathrm{~V} \text {, fre- } \\
\text { quency } 20 \mathrm{kHz} \text {, maximum yield } \\
9.73 \% \text {. }\end{array}$ & - & - & - & $\begin{array}{l}\text { Antioxidant } \\
\text { property }\end{array}$ & $\begin{array}{l}\text { Yang., et al. } \\
\text { (2016) }\end{array}$ \\
\hline $\begin{array}{l}\text { Allium } \\
\text { sativum }\end{array}$ & $\begin{array}{l}\text { Hot water } \\
\text { extraction }\end{array}$ & $\begin{array}{l}\text { Temperature } 21^{\circ} \mathrm{C} \text {, time } 30 \mathrm{~min}, \\
\text { extraction yield } 29 \%\end{array}$ & $\begin{array}{c}\text { Fructose, glucose, } \\
\text { galactose }\end{array}$ & $7.35 \mathrm{kDa}$ & $\begin{array}{l}\beta \text {-glycosidic } \\
\text { bond }\end{array}$ & Antioxidant & $\begin{array}{c}\text { Chen and } \\
\text { Huang } \\
\text { (2018) }\end{array}$ \\
\hline $\begin{array}{l}\text { Allium } \\
\text { ursinum }\end{array}$ & $\begin{array}{l}\text { Subcriti- } \\
\text { cal water } \\
\text { extraction }\end{array}$ & $\begin{array}{c}\text { Temperature } 120^{\circ} \mathrm{C} \text {, time } \\
20 \text { min,Maximum yield } 55.05 \%\end{array}$ & - & - & - & Antioxidants & $\begin{array}{l}\text { Tomsik., et } \\
\text { al. (2017) }\end{array}$ \\
\hline $\begin{array}{l}\text { Allium } \\
\text { cepa }\end{array}$ & $\begin{array}{l}\text { Solvent } \\
\text { extraction }\end{array}$ & $\begin{array}{c}\text { Temperature } 70^{\circ} \mathrm{C} \text {, time } 60 \mathrm{~min} \text {, } \\
\text { extraction yield } 89.92 \%\end{array}$ & \begin{tabular}{|c|} 
Rhamnose, \\
arabinose, xylose, \\
mannose, galac- \\
tose, glucose \\
\end{tabular} & $7.02 \mathrm{kDa}$ & $\begin{array}{l}\beta \text { glycosidic } \\
\text { bond }\end{array}$ & Antioxidant & $\begin{array}{l}\text { Zhu., et al. } \\
\text { (2017) }\end{array}$ \\
\hline
\end{tabular}

Table 5. Extraction, physicochemical and structural characteristics, and bioactivities of PSs from other Allium species. 


\section{Conclusion and Future Perspectives}

Several interventions by world-recognized organizations such as WHO formulates several policies to reduce the incidence of noncommunicable diseases of which cardiovascular disease, metabolic diseases and cancer are the predominate ones. Numerous studies have delved into the biological and pharmacological properties of dietary polysaccharides as effective in preventing and managing such conditions and it is attributed to its antioxidant, immunomodulatory, anti-hypertensive, anti-diabetes, anti-allergic, anti-cancer, and gastro-protective functions. Allium species of the Alliaceae family of which garlic and onion have been widely produced all over the globe with the highest production countries been China and India have been wide used as a traditional medicine in China for the treatment of numerous diseases such as cancer, diabetes, hypertension, coronary heart diseases, cancer, obesity, hypercholesterolemia, cataract as well as treatment of bacterial, fungal, viral and parasitic infections. The presence of the organosulfur compound in Allium species has also been extensively studied and it is found out to contain alliin, allicin, ajoene, captopril etc. Various extraction methods have been used to extract the bioactive biomolecules from Allium species. The oldest, which is the solvent extraction method, has been used since 1879 and it is still used as a standard method against modern methods like the ultrasound, microwave, supercritical, pulse electric field and enzyme assisted extraction methods. The structural characterizations of these bioactive biomolecules, including monosaccharide composition, molecular weight, configuration and position of glycosidic linkages have been clarified. However, the current procedure for the isolation of polysaccharides is very tiresome and complicated and is only useful for analytical or preparative purposed in the laboratory and unsuitable for large scale processing also further studies need to be done to better explain the mechanism of the biochemical processes of Allium species.

\section{Bibliography}

1. Abbas H M K., et al. "Antimicrobial Potential of Genes from Garlic (Allium sativum L.)". In Studies on Garlic. IntechOpen (2019).

2. Ajayi GO., et al. "Hepatoprotective and some haematological effects of Allium sativum and vitamin C in lead-exposed wistar rats". International Journal of Medicine and Medical Sciences 1.3 (2009): 64-67.

3. Al-Snafi AE. "Antiparasitic effects of medicinal plants (part 1)-A review". IOSR Journal of Pharmacy 6.10 (2016): 51-66.

4. Alonso-Salces RM., et al. "Pressurized liquid extraction for the determination of polyphenols in apple". Journal of Chromatography A 933 (2001): 37-43.

5. Anthony JP., et al. "Plant active components-a resource for antiparasitic agents?" Trends in Parasitology 21.10 (2005): 462468.
6. Apolinário AC., et al. "Inulin-type fructans: A review on different aspects of biochemical and pharmaceutical technology". Carbohydrate Polymers 101 (2014): 368-378.

7. Archer JC and Jenkins Jr RG. "Automated milk fat extraction for the analyses of persistent organic pollutants". Journal of Chromatography B 1041 (2017): 70-76.

8. Astaneh R K., et al. "The effects of selenium on some physiological traits and $\mathrm{K}, \mathrm{Na}$ concentration of garlic (Allium sativum L.) under $\mathrm{NaCl}$ stress". Information Processing in Agriculture 5.1 (2018): 156-161.

9. Azwanida NN. "A review on the extraction methods use in medicinal plants, principle, strength and limitation". Medicinal and Aromatic Plants 4.196 (2015): 412-2167.

10. Barazani O., et al. "Cadmium accumulation in Allium schoenoprasum L. grown in an aqueous medium". Chemosphere 57.9 (2004): 1213-1218.

11. Batchu S N., et al. "Bioactive Compounds in Heart Disease". Bioactive Food as Dietary Interventions for Cardiovascular Disease: Bioactive Foods in Chronic Disease States 431 (2012).

12. Baumgartner S., et al. "Characterisation of the high-molecular weight fructan isolated from garlic (Allium sativum L.)". Carbohydrate Research 328.2 (2000): 177-183.

13. Benítez V., et al. "Onion (Allium cepa L.) by-products as source of dietary fiber: physicochemical properties and effect on serum lipid levels in high-fat fed rats". European Food Research and Technology 234.4 (2012): 617-625.

14. Beusterien K., et al. "Use of conjoint analysis to assess breast cancer patient preferences for chemotherapy side effects". The Oncologist 19.2 (2014): 127-134.

15. Block E., et al. "Allium chemistry: HPLC analysis of thiosulfinates from onion, garlic, wild garlic (ramsoms): leek, scallion, shallot, elephant (great-headed) garlic, chive, and Chinese chive. Uniquely high allyl to methyl ratios in some garlic samples". Journal of Agricultural and Food Chemistry 40 (1992): 2418-2430.

16. Boulila A., et al. "Enzyme-assisted extraction of bioactive compounds from bay leaves (Laurus nobilis L.)". Industrial Crops and Products 74 (2015): 485-493.

17. Bray F., et al. "Global cancer statistics 2018: GLOBOCAN estimates of incidence and mortality worldwide for 36 cancers in 185 countries". CA: A Cancer Journal for Clinicians 68.6 (2018): 394-424.

18. Capasso A. "Antioxidant action and therapeutic efficacy of Allium sativum L". Molecules 18.1 (2013): 690-700. 
19. Carr A G., et al. "A review of subcritical water as a solvent and its utilisation for the processing of hydrophobic organic compounds". Chemical Engineering Journal 172 (2011): 1-17.

20. Chandrashekar PM., et al. "Isolation, structural elucidation and immunomodulatory activity of fructans from aged garlic extract". Phytochemistry 72 (2011): 255-264.

21. Chandrashekara PM and Venkatesh YP. "Immunostimulatory properties of fructans derived from raw garlic (Allium sativum L.)". Bioactive Carbohydrates and Dietary Fibre 8 (2016): 6570.

22. Charlotta Turner. "Modern Extraction Techniques Food and Agricultural Samples. American Chemical Society". Division of Agricultural and Food Chemistry (1970).

23. Chemat F., et al. "Ultrasound assisted extraction of food and natural products. Mechanisms, techniques, combinations, protocols and applications. A review". Ultrasonics Sonochemistry 34 (2017): 540-560.

24. Chen HF, et al. "Two new steroidal saponins from Allium macrostemon Bunge and their cytotoxity on different cancer cell lines". Molecules 14 (2009): 2246-2253.

25. Chen J and Huang G. "Antioxidant activities of garlic polysaccharide and its phosphorylated derivative". International Journal of Biological Macromolecules 125 (2019): 432-435.

26. Cheng $\mathrm{H}$ and Huang G. "Extraction, characterisation and antioxidant activity of Allium sativum polysaccharide". International Journal of Biological Macromolecules 114 (2018): 415419.

27. Chope GA., et al. "Alliums (Onion, Garlic, Leek and Shallot)". Health-Promoting Properties of Fruits and Vegetables (2011): 5-28.

28. Csiszar J., et al. "Antioxidant enzyme activities in Allium species and their cultivars under water stress". Plant Soil and Environment 53.12 (2007): 517.

29. Cui SW. "Food carbohydrates: chemistry, physical properties, and applications". CRC press (2005).

30. de Camargo AC., et al. "Enzyme-assisted extraction of phenolics from winemaking by-products: Antioxidant potential and inhibition of alpha-glucosidase and lipase activities". Food Chemistry 212 (2016): 395-402.

31. De Castro MDL and Garcia-Ayuso LE. "Soxhlet extraction of solid materials: an outdated technique with a promising innovative future". Analytica Chimica Acta 369 (1998): 1-10.

32. De Castro MDL and Priego-Capote F. "Soxhlet extraction: Past and present panacea". Journal of Chromatography A 1217.16 (2010): 2383-2389.
33. Diriba-Shiferaw G., et al. "Bulb quality of Garlic (Allium sativum L.) as influenced by the application of inorganic fertilizers". African Journal of Agricultural Research 8 (2013): 53875398.

34. Djurdjevic L., et al. "Allelopathic potential of Allium ursinum L". Biochemical Systematics and Ecology 32.6 (2004): 533-544.

35. Dominguez $\mathrm{H}$ and Munoz MJG. Water Extraction of Bioactive Compounds: From Plants to Drug Development. Elsevier (2017).

36. Dorhoi A., et al. "Modulatory effects of several herbal extracts on avian peripheral blood cell immune responses". Phytotherapy Research: An International Journal Devoted to Pharmacological and Toxicological Evaluation of Natural Product Derivatives 20.5 (2006): 352-358.

37. Dziri S., et al. "Phenolic constituents, antioxidant and antimicrobial activities of rosy garlic (Allium roseum var. odoratissimum)". Journal of Functional Foods 4.2 (2012): 423-432.

38. Ebringerova A and Heinze T. "Xylan and xylan derivativesbiopolymers with valuable properties, 1 . Naturally occurring xylans structures, isolation procedures and properties". Macromolecular Rapid Communications 21.9 (2000): 542-556.

39. Eksi G., et al. "Fortification of Functional and Medicinal Beverages With Botanical Products and Their Analysis". In Engineering Tools in the Beverage Industry (2019): 351-404.

40. Emami S., et al. "The effect of garlic intake on glycemic control in humans: a systematic review and meta-analysis". Progress in Nutrition 19 (2017): 10-18.

41. Eskilsson CS and Björklund E. "Analytical-scale microwave-assisted extraction". Journal of Chromatography A 902.1 (2000): 227-250.

42. Foster BC., et al. "An in vitro evaluation of human cytochrome P450 3A4 and P-glycoprotein inhibition by garlic". Journal of Pharmacy and Pharmaceutical Sciences 4 (2001): 176-184.

43. Gao Z., et al. "Optimization of selenylation modification for garlic polysaccharide based on immune-enhancing activity". Carbohydrate Polymers 136 (2016): 560-569.

44. Golovchenko VV., et al. "Structure of pectic polysaccharides isolated from onion Allium cepa L. using a simulated gastric medium and their effect on intestinal absorption". Food Chemistry 134.2 (2012): 1813-1822.

45. Gonçalves CB., et al. "Partition of nutraceutical compounds in deacidification of palm oil by solvent extraction". Journal of Food Engineering 81.1 (2007): 21-26.

46. Goncharov N., et al. "Organosulfur compounds as nutraceuticals". In Nutraceuticals (2016): 555-568. 
47. Goren A., et al. "Antiviral composition derived from allium CEPA and therapeutic use thereof". Google Patents (2002).

48. Griffiths G., et al. "Onions-a global benefit to health". Phytotherapy Research 16.7 (2002): 603-615.

49. Grimmer G. "Environmental carcinogens: polycyclic aromatic hydrocarbons". Crc Press (2018).

50. Han SB., et al. "The inhibitory effect of polysaccharides isolated from Phellinus linteus on tumor growth and metastasis". Immunopharmacology 41.2 (1999): 157-164.

\section{Assets from publication with us}

- Prompt Acknowledgement after receiving the article

- Thorough Double blinded peer review

- Rapid Publication

- Issue of Publication Certificate

- High visibility of your Published work

Website: www.actascientific.com/

Submit Article: www.actascientific.com/submission.php

Email us: editor@actascientific.com

Contact us: +919182824667 